\title{
Is Genetic Labeling of "Risk" Related to \\ Obesity Contributing to Resistance and \\ Fatalism in Polynesian Communities?
}

\section{Lena Rodriguez and James Rimumutu George}

Polynesians, ${ }^{1}$ Indigenous Australians, and Native Americans are among the highest-risk groups for obesity in the world, with Polynesians having the leading rates for type 2 diabetes and heart disease (NZMH 2OI $3 \mathrm{a}$, $20 \mathrm{I} 3 \mathrm{~b}){ }^{2}$ The incidence, trajectory, and outcomes of obesity are particularly marked in poor and marginalized communities. Along with increased consumption of poor-quality commercialized foods and an increasingly sedentary lifestyle, socioeconomic factors and ethnicity have been identified as the most likely predictors of obesity, associated ill health, and premature mortality (see, eg, Ferreira and Lang 2006; Fujita, Braun, and Hughes 2004).

As many Polynesians are clustered in the lowest socioeconomic percentiles, they experience the patterns of poor health literacy, late diagnosis, inadequate treatment, and high rates of premature death that are common among other indigenous groups as well as in Anglo workingclass communities. In this article, we explore how publicity concerning genetic risk among members of Polynesian communities in Australia may contribute to a fatalism about acquiring such illnesses and reluctance to seek diagnosis and treatment. We also examine some of the socioeconomic and cultural reasons behind the reticence of Polynesians to have regular health checks and to engage with preventative health measures regarding illnesses afflicting so many in the community.

\section{Demographic Background of Participants}

Māori and Pacific Islander migrants are currently one of Australia's fastest growing immigrant groups, with a current conservative population esti-

The Contemporary Pacific, Volume 26, Number 1, 65-93

(C) 2014 by University of Hawai'i Press 
mate of I 26,000 (Rodriguez 20I2). ${ }^{3}$ In addition, Samoans and Tongans, who even a decade ago would have gone to New Zealand, are now arriving in Australia in significant numbers directly from the home islands.

In the $20 \mathrm{I} 2$ study discussed in this article, the majority of adult participants, including Islanders, were born in New Zealand. Age of migration for the primary economic migrant was typically in the mid to late $20 s$. Most children in the household studies were born in Australia. In most cases, the family respondents were themselves the "economic migrants" who moved to Australia for work. Average length of time since migration was I 3.5 years. A clear majority of these participants admitted leaving school "early," the equivalent of year Io in Australia (with year I 2 being the final year of secondary school). These participants remain unskilled, with a small number engaged in semiskilled work such as bookkeeping and building and allied trades. In discussions within the family groups, people expressed the expectation that the next generation would have improved educational opportunities and subsequent career choices. Among the young people (aged I 8-25), who were interviewed individually or in focus groups, approximately one-third were studying or were intending to study at the tertiary level. The majority of these participants planned to enter teaching, nursing, or social work. For these younger participants, slightly more females than males were entering tertiary education.

While the average weekly income of the families (US\$2,908) may appear high, when household population densities are taken into consideration, this is radically reduced: the average household composition was 9.5 persons. This is almost four times the number of people in Anglo-Australian households (ABS 2006). In addition, the cost of living in Australia, in particular the cost of housing, is extremely high. For Pacific Islanders, sending remittances to the home islands and paying tithes to churches further erode disposable household income, contributing to a lower overall socioeconomic status than may be initially indicated by household income.

\section{Method}

In order to examine the impact of health issues for Polynesians in a migrant context, it is necessary to explore and include culturally specific ways of perceiving the world, the body, and culturally embedded notions of health and illness. As Kabini Sanga pointed out, the methodology chosen to do this involves a responsibility in "describing knowledge, explaining and reporting it [that] must allow for backgrounds, multiple realities, 
processes and contextual protocols to be captured" $(2004,47)$. The first author conducted the qualitative study discussed in this article, working within a framework of Kaupapa Māori. Kaupapa, both in theory and in methodological practice, provides a cultural paradigm in relation to Māori and more broadly, with local adaptations, Pacific Islanders. This methodology enables the incorporation of colonial history, the impact of social disadvantage, and understandings regarding linguistic and conceptual associations relevant to Polynesians and their localized perceptions of health (Williams and others 2003; Cram 2001).

Kaupapa is not premised on hypothesis testing but rather allows concepts and ideas to emerge from the data and from the research process itself. This provides flexibility in the use of direct and indirect questions, semi-structured interviews, narrative, and cultural context. For example, participants were not asked directly about their health status. Instead they were allowed to tell their own stories, in which descriptions of their health-and that of other family members-were embedded. In this study, sixty-seven Polynesians were interviewed, including three key respondents: two male nurses (one Māori and one Niuean) and one female nurse (Māori). The key respondents were able to offer valuable insights into the interactions of Polynesians with mainstream health services. Some participants were interviewed as a family, while others were interviewed individually or as part of two focus groups (see table I). Recruitment was carried out using "snowballing" in the context of the extended Polynesian communities of Sydney and regional New South Wales. ${ }^{4}$ Ethnicity was self-identified. Interviews were conducted in English with family translators available for Pacific Islander participants. Participants were required

Table I. Interviews with Participants

\begin{tabular}{lcc}
\hline Type of interview & Number of participants & Number of interviews \\
\hline Family & 40 & 9 \\
Focus group & 15 & 2 \\
Key informant & 3 & 6 \\
Other individual & 9 & 9 \\
$\quad$ Total & 67 & \\
\hline
\end{tabular}


to be over the age of eighteen. Data was hand-coded into themes concerning cultural understandings of the body, health and wellness, and the experience of obesity-related illness.

Details of family compositions, household densities, and migration histories are given in appendix A of this essay. A summary of individual and focus-group participants is given in appendix B.

\section{BACKGROUND Discussion}

There is now considerable discussion among health sociologists, medical anthropologists, and others regarding the Eurocentric nature of the Body Mass Index (BмI) itself. E Gonda and K Katayama (2006) and P Craig and others (2003) have argued for a different scale to be used for Polynesians because of their greater bulk density ratio to height, and this suggested innovation may well be introduced in the future. However, regardless of how obesity is measured, Polynesians occupy the highest band of obesityrelated statistics and remain "at risk" of complications because of being overweight. Approximately one in four Māori and Pacific Islander adults are obese by the accepted biometric measures, and detailed analysis of statistics also indicates a disturbing trend: that rates of obesity are increasing in these communities (Obesity Task Force 2008). As these figures also reveal, the statistics for extreme obesity reveal an even greater concentration of Polynesians.

These obesity rates have led to a concomitant rise in type 2 diabetes. The link between obesity and type 2 diabetes is so marked that the term "diabesity" is now frequently used to better describe the association (Zimmet 2005). In 2006, New Zealand figures showed that type 2 diabetes was accountable for 20 percent of all deaths among Māori, compared with 4 percent for non-Polynesian people in New Zealand (Diabetes in Control 2006). Similar statistics are available for other Pacific Islander groups; for example, a recent study for the University of Hawai'i (reported in Consillio 2013) confirmed that nearly 70 percent of Native Hawaiians are obese (see also OMH 20I2), and the rates of premature death from untreated type 2 diabetes are significantly higher for Native Hawaiians than for other ethnic groups (Furubayashi and Look 2005).

Analysis of medical data allows an appreciation of the urgency and severity of the situation confronting Polynesian communities and those responsible for their care (Bedford and others 2009; Zimmet 2005; Zimmet and others 200I). Central to this discussion are Western notions of 
obesity, its causes, and its impacts. In relation to type 2 diabetes, it is generally accepted that a series of interrelated factors including genetic predisposition, ethnicity, lifestyle, and socioeconomic status contribute to high rates of this illness (Furubayashi and Look 2005; Zimmet and Thomas 2003). However, as Virginia Chang and Nicholas Christakis have observed (2000), in the United States, obesity and related illnesses are progressively being described in medicalized and genetic terms rather than being regarded as a result of socioeconomic influences.

Such biomedical and genetic explanations have implications when applied to specific ethnic groups and not others. Arguably, this constitutes a form of "biocolonialism" as an unintended consequence of singling out particular populations (Harry 200I). Hannah Bradby developed this view by putting these practices into a historical context: "The moral value of scientific knowledge depends on the use to which it is put, and the historical precedence of the abuse of theories of inheritance against groups of people, including those distinguished by their ethnicity, has brought an urgency to concerns as to how the new genetics might be used against people" (2000, 295).

This is not to suggest that modern geneticists are intending to cause harm in any way. Rather, it is our intention to raise awareness of the impact of such explanations because they may lead to feelings of hopelessness and resignation regarding an illness that may in other ways be considered preventable, or at least manageable. In this sense, we are concerned with how information regarding genetic "risk" is disseminated and, importantly, how this information is received and internalized by the recipient population.

\section{The “Obesity/Thrifty” Gene Debate in Relation to Polynesians}

As Polynesians repeatedly appear in international studies regarding high rates of obesity and diabetes, the physical makeup of Polynesians is under scrutiny by the scientific community. The "genetic argument" suggests that Polynesians are host to two genetic systems relevant to this discussion: first, the "obesity" or "thrifty" genotype and, second, a genetic predisposition to diabetes. This section briefly outlines the issues surrounding this position in which the Polynesian genetic profile has a central role.

The significant seafaring feats of ancient Polynesians form the background of the "obesity/thrifty" gene hypothesis originally proposed by 
James Neel in 1962 and modified in 1982 (Neel I962, I982). His premise was that Polynesian sailors spent extended periods of time without food and were utilizing an underlying gene that enabled them to store large amounts of fat to sustain them both during long voyages and during cycles of famine. Despite this premise being refuted by oral histories and archaeological evidence (see Davis I992; Rodriguez 2009), Neel maintained that modern obesity is a result of the gene lying dormant and being reactivated in a manner that is no longer appropriate.

Other researchers in the debate surrounding genetics, ethnicity, and health argue that genetics alone cannot explain the current phenomenon of escalating and accelerating obesity rates in Polynesians (Pearce and others 2004; Foliaki and Pearce 2003). Epidemiological studies, including that of Hilary King, Ronald Aubert, and William Herman (1998), have predicted a global increase of 170 percent in type 2 diabetes by 2025 . The social geography of these trends is that the greatest concentrations are in the working-class, non-Anglo migrant, and marginalized postcolonial communities, with Polynesians heavily represented in this pattern (see also Page and others 2007; McCarty and Zimmet 200I).

From the perspective of health sociology, evidence suggests that morbid obesity - that is, a compromised health status due to being extremely overweight - results from a tapestry of issues and circumstances that coalesce around social and economic disadvantage, postcolonial cultural impoverishment, and possible genetic propensity (Durie 2003). For example, some studies suggest that Polynesians have a tendency toward poor insulin absorption and possible glucose intolerance (see New Zealand Herald 2006; Sundborn and others 2007; Sundborn and others 2008). However, other researchers have argued that the corresponding increase in obesity in these same populations could indicate that the preconditions for diabetes and associated conditions may well be triggered and exacerbated by the state of obesity itself effectively distorting the metabolic status (Montoya 2007; Foliaki and Pearce 2003). These authors therefore mount the argument that, although genetics do play a part in health and illness, the contribution of environmental factors is underestimated and disease may be misattributed to a genetic cause. For example, in the case of families with high rates of obesity-related illness, it should not be surprising that many family members should present with these symptoms: "It is often assumed that diseases are genetic because they run in families, but this often reflects a common environment and lifestyle rather than a genetic influence" (Pearce and others 2004, 1070). 


\section{Criticism of the “Thrifty Gene” Hypothesis}

To the lay public, genetics represents the frontier of new science, promising diagnostic breakthroughs that will be used to accurately predict and identify "high risk" candidates for specific illnesses. However, as Barbara Clayton observed (2002), genes have only been proven to play a small and highly unpredictable role in the way a disease may manifest in a particular body. World Health Organization (wHO) researcher and international diabetes campaigner Paul Zimmet and his coauthor, Dr Charles Thomas, are also aware of these limitations: "Despite a great investment of both resources and money into candidate and genome-wide linkagebased approaches, the results so far in terms of identification of the thrifty, and indeed obesity and type 2 diabetes genes, have been disappointing" (2003, II 8 ).

The "thrifty gene" hypothesis, while unproved, effectively serves to redirect the attention of health workers and policy makers from other socioeconomic and cultural triggers of obesity. This means that more complex interactive factors contributing to obesity in certain populations remain unaddressed, while significant research funding is allocated to pursuing a genetic explanation. The reluctance of government officials and health professionals to engage with the deeper underlying causes of illness in Indigenous communities has been described by Nancy Scheper-Hughes as "the tendency to 'normalize' suffering, disease, and premature death among certain excluded or marginalized classes and populations" (2006, xviii). In other words, the dominance of the "faulty genes" explanation for otherwise preventable illnesses serves to justify both political complacence and medical failure in regard to such communities. This perspective lays the blame for illness on the most disenfranchised: "The prevailing medical model of diabetes etiology focuses on the 'faulty genes' of Indigenous Peoples combined with their faulty diets and other unhealthy behaviors. [These are] victim-blaming hypotheses that only serve to trap the sick person inside a cage of disease that is seemingly of their own making" (Scheper-Hughes 2006, xviii).

The known factors that do contribute to obesity—such as a high calorie diet, sedentary lifestyle, and poor health literacy—require long-term support and interventions that are expensive and time consuming, rendering them unpopular in political terms (Duckett 2008). In this way, "blaming the victims" for their genetic predispositions and poor lifestyle choices 
allows macro policies for complex conditions to be ignored, and prevents tackling the issue in an integrated way.

\section{Gene/EnVIronment InTERACTIVIty}

As many geneticists appreciate, there is a need to explain how environmental factors interact with genetic "programming" (Stauffer and DeSouza 20I0). The emerging field of epigenetics explores changes in gene expression that occur without a change in DNA sequence. Factors being explored by Brian Stauffer and Christopher DeSouza, among others, include living in sustained emotional states that are adverse to well-being, such as those induced by long-term poverty. Such work may help advance understanding of these complex interactions. Statistics for obesity-related illnesses in Polynesian as well as other Indigenous and colonized populations may indicate that there is not necessarily a single genetic profile common to these groups, but rather a comparable concentration of socioeconomic disadvantage, cultural marginalization, and poor health that initiates a "genetic" maladaption (Rodriguez 201 2, 2009; Pearce and others 2004). In this view, epidemiological clusters should be explored with these significant variables in mind.

\section{Discussion and Analysis}

\section{Overview of Participant Experience of Obesity-Related Illnesses}

All participants in this study admitted to being affected by the issue of obesity-related illness in both their immediate and extended families. Being part of a low socioeconomic demographic, coupled with poor health literacy, many participants identified cultural, financial, and structural barriers to being tested for type 2 diabetes, heart disease, and related ailments. The following story was typical of many told during this study and reflects the range of compounding factors affecting health access. This Tongan woman sharing her personal account acts as a voluntary interpreter for her extended community in a regional area:

Islanders are very shy-they just won't talk. If you push them, they'll shut up even more. It makes it very difficult. I had a cousin visiting Australia, and I was so shocked when I went to say goodbye and my relatives said, "Did you know he had diabetes? He's very upset he can't afford the medicine." He didn't want to bother me because he knows I have family problems and I am so busy. I asked him if he went to the doctor, and he said: "Yes I did—but they told me 
to go and buy this and that." Sometimes they've got the money and they get the treatment, and sometimes they don't have the money and don't go. Financially they are very poor-they get embarrassed. Now he has passed away. (Tongan female, 45)

Economic reasons for not pursuing medical diagnosis and treatment were frequently cited. However, another theme emerged relating to the perceived inevitability of genetic determinants of illness that appears related to the experience of watching so many family and community members suffer disability and premature death. As an example: "My brother had to have his leg taken off [from complications of diabetes]. It's in our family. I'm worried it's going to be me next" (Samoan male, 27). There were elements of both fear and resignation in relation to this commonly held perception: "It's just how it is, you know, for us Polys [sic], it's in the genes. We die early from diabetes and that" (Māori male, mid zos). The key respondents, all Polynesian nurses, repeatedly expressed frustration that most obesity-related illnesses should be regarded as preventable, but the message does not seem to be getting through: "We spend our lives at funerals. It's just wrong. These illnesses should not be fatal" (Māori male nurse, key respondent). For the key respondents, it was difficult to reconcile their Western training and understandings of how obesity leads to many other illnesses with their relationship with community and family members. They feel caught in the middle trying to explain cultural practices to Anglo health professionals and explain Western understandings of health to their communities: "We desperately need more people trained up. Not everyone is going to become a nurse or a doctor, but we need more Polynesian paramedics/nursing aides in our communities. People who are trained but can still sit down and not rush. Explain what's going on to people ... and listen to them as well" (Māori female nurse, key respondent).

\section{Localized Notions of the Body and Food Practices}

Alexandra Brewis and her coauthors explored self-perceptions of the body by surveying Samoans in New Zealand and in the home islands (1998). Their conclusions were somewhat contradictory in the sense that the "ideal" body size was accepted to be slim, and some dissatisfaction was expressed about being unable to lose weight. However, individually, people did not perceive themselves to be obese and they remained positive regarding their own body size and health. That contradiction was also 
evident in the study under discussion here. The majority of younger participants (under 30 years of age) expressed being influenced by the Western discourse equating slimness with beauty and attractiveness, and many admitted to trying to lose weight; for instance: "I try and watch what I eat here [in Australia] - I don't want to end up enormous like the cuzzies back home, but it's hard. Everyone gives you a hard time like you're not a real Islander unless you're huge. I was skinny as a kid, and they wouldn't choose me to dance 'cos I didn't look like a Tongan. . . . You want to fit in with the other girls at school, and they all want to be skinny-everywhere you look, TV and that, everyone's skinny" (Tongan female, 22).

Modern Western concepts of the slim "civilized body" have come to symbolize restraint, personal discipline, and health (Shilling 2003; Lupton I996). This is in direct contrast to the Polynesian view of the positive social values associated with a large body-physical beauty, health, and strength. The normalization of the large body has a complex anthropological and cultural history in Polynesia. However, the modern Polynesian body is arguably exceeding historical patterns: "Thinking back, basically Polynesians were fine built people-active fishing and gardening. Only the wealthy were plump like the royal family in Hawai' $i$, so most people would have been fitter-not too skinny, not too fat, just average" (Tongan grandmother, 85).

The concern now for many health workers is that the Polynesian acceptance and even cultivation of a large body is blurring the message in regard to obesity and ill health. A key respondent, a male Niuean nurse, explained how the large/obese body is viewed in his community:

Obesity is not questioned in our community. It is the norm. People still believe that you need to be fat to be healthy. Even though they see all the complications around them and the discomfort, they don't want to do things differently. They don't see their obesity as the problem. The thing is that their weight is stopping them from leading full lives, but they don't care-they socialize with their families and they are all fat-so it gets reinforced. If you are thin, people criticize you and think you're weird. Not only weird, but probably sick as well. To a Māori or Islander, to be thin is to be weak.

Such a localized understanding reflects the embedded notions of health, strength, and power represented by a large body, a view that was commonly expressed among participants. In addition, extensive social reciprocities are enacted around food exchange rituals and feasting and underlie all aspects of Polynesian cultural life. Jane Lassetter's 20 Io qualitative 
study of Hawaiian migrants to the continental United States reveals that not only is excessive eating regarded as enactment of cultural practice, but it is also considered to have beneficial social and psychological effects such as offsetting homesickness in the diasporic community. The scale of Polynesian eating is reflected in one respondent's description of a "Kanak Attack," the culturally sanctioned practice of overeating: "[Polynesians] just eat. You don't eat till you're full ... you eat till you're tired" (quoted in Lassetter 2010, 67).

\section{The Role of Health Literacy}

In a modern context, however, this cultural endorsement of overeating exacerbates existing correlations between social disadvantage, obesity, and chronic ill health. These correlations are circulatory in nature: statistically obesity is associated with economic disadvantage, and the stigma of obesity furthers disadvantage through ill health and diminished job prospects (Zhang and Wang 2004). Social disadvantage and culturally prescribed perceptions and behaviors coalesce around the issue of health literacy. In a 2000 study, David Simmons, Tim Kenealy, and D J Scott found that low levels of Western health understandings and factual information about type 2 diabetes and other serious obesity-related diseases among Polynesians have implications both in terms of individual health and also for health practitioners (Simmons and others 2000). The incidence of such illnesses appears high, while awareness of the nature, symptoms, or complications of type 2 diabetes, for example, is extremely low. This finding was also apparent in our analysis, especially regarding older respondents (over the age of 50 ). As all three key respondents pointed out, it is difficult to encourage community members to engage with conventional preventative measures recommended by Western health professionals: "In many ways our community is suffering from diseases that are preventable. They just don't make the connection between their lifestyle-particularly what they eat—and how they get sick. They don't know what the symptoms are of the early signs of diabetes, or gout, or heart conditions, so they just plod on. It's really hard to get them to seek medical attention. So it's the double whammy - they don't know how to prevent these things [from] happening, and then, even when they get symptoms they really shouldn't ignore, they won't go to hospital" (Māori female nurse, key respondent).

In other cases, people are offered services but may be reluctant to participate. In Hawai'i, for example, while there are widely available programs for the management of diabetes, only 55 percent of Native Hawai- 
ians diagnosed with diabetes accessed these resources during the trajectory of their illness (Furubayashi and Look 2005, I08). This would indicate the existence of other forms of cultural and possibly class resistance to these approaches. In other words, it could well be that the clinical biomedical approach itself is off-putting rather than people simply "choosing" to not participate.

\section{Health Promotions to Alleviate Obesity:} A Middle-Class Discourse?

In the Western health paradigm, obesity is regarded as both a medical problem and a personal issue (Lupton 1996, 2003; Chang and Christakis 2000). This is reflected in the notion of "healthism," the nexus of food and lifestyle whereby individuals are expected to take responsibility for their own health status. This emphasis on individual responsibility for health has been accompanied by an expectation that people have a civic responsibility to change their own lifestyle behaviors. As pointed out by Clayton (2002), individuals are expected to absorb this information and incorporate it into their lives or risk being labeled recalcitrant. Implicit is the expectation that people should change their intrinsic cultural behaviors in relation to what others have deemed problematic.

Most participants in this study expressed a disengagement from the discourse surrounding individual health, preferring to operate within a framework of "wellness" or "well-being" that is associated with the collective or sociocentric family structures of Polynesians: "To a Māori, food is where it's at. Food is better than sex. There's nothing beats sitting down with your whanau [family] and having a gigantic feed-then you have a nap" (Māori male, mid 4os).

With cultural associations of being generous with food and a perception of obesity as normal, even desirable, Polynesians are unlikely to respond to health directives that simply say "eat less." Nutrition advisors attached to public health initiatives in weight loss suggest moderate intakes of the major food groups in specific quantities. But this fails to resonate with the Polynesian community: "What's with the food pyramid? That is not going to go down in a Māori house, I can tell you. Two serves of this and that ... we have a loaf of bread with every meal, and that's per person!" (Māori female, 35). As the Niuean key respondent reported: "You can tell Polynesians about the 'tick' for a healthy heart and bring out the tape measures and try to scare them, but it won't go in. Two serves of fruit and 
five veggies isn't going to cut it-they don't see that as related to their health. They feel happy if they're eating, and that is almost more valuable than being 'healthy' to a Western person." Another participant contributed: "Polynesians will eat a carload of Kentucky Fried Chicken and then go home for dinner" (Samoan male, 28). Implied in this statement is that although an individual may eat a takeaway meal alone or in company, the "real meal" is with the family. This is the setting in which the positive values associated with family are reiterated; the sharing of familiar foods therefore takes precedence over an individual's designated dietary requirements.

Further, how individuals rank their own health may not be a priority in socially stressed, marginalized communities. For example, a Polynesian parent might be more worried about his or her children going to jail than about having a diabetes test. One of the older participants outlined her immediate concerns: "They tell us to watch what we eat, but I'm stressed enough as it is. My sister is dying of lung cancer, my husband passed away last year with heart problems, and my daughter has lost her job. Now my youngest boy is playing up and I have to go to court on Monday" (Tongan female, 53). This brief story affirms Daniela Heil's findings regarding Aboriginal health and well-being in rural Australia (2009). Heil's work demonstrates that for sociocentric communities, perceptions of health and well-being are relational: the wellness and security of those making up the social group hold greater significance than the biomedical health status of the individual. By contrast, the middle-class/Anglo thrust of health promotion campaigns is directed exclusively at the individual, urging moderate food intake as well as complete abstinence from certain "bad" foods. Such restraint is then ostensibly rewarded by good health. However, this message is incongruous, antisocial, and somewhat alien to Polynesians, who socialize around the consumption and exchange of inordinate amounts of food.

This association between eating "Polynesian style" and perceived "health" is a difficult nexus to challenge: "Islanders find it hard to change their diet-if we change our diet, we become more unhealthy" (Samoan female, 40). Within Polynesian cultural practice, notions of well-being are deeply entwined with the process of shared eating, food ritual, and food exchange. Therefore the idea that food should be "rationed" for health reasons is commonly regarded as antithetical to well-being.

For those who are caregivers in their extended family, it is often very difficult to be the "gatekeeper" of dietary intake for a relative, particularly 
an older relative. For example, a Samoan participant whose wife was very ill with diabetes and heart complaints expressed some degree of agitation that their daughter should be trying to limit the mother's intake of foods deemed inappropriate by her doctors: "How's my wife going to recover if she can't eat Island food? Where's she going to get her strength from? I get angry with my daughter-doesn't she want her mother to get well?" (Samoan male, 44). It should be noted in this context that "Island food" may refer to certain healthy traditional dishes of fresh fish and fruit; however, it also commonly means, as in this case, eating "like an Islander"eating large amounts of food, both traditionally prepared and Western, processed food.

Similar stories emerged throughout the interview process. In one Māori family, the siblings who were not caregivers were critical of their brother's attempts to restrict the food given to the diabetic mother: "Mum's supposed to be on this really strict diet. She just wanted some chippies [French fries], and my brother accused me of being mean [because of] not letting her eat what she wants, but I'm the one that has to front up to the doctor. Mum loves everything in batter, especially homemade Māori bread, which is really just saturated fat. I can't get my brothers and sisters to monitor her eating when I'm not there" (Māori male, 45).

Younger participants (under age 35 ) demonstrated a better understanding of the correlation between lifestyle, food intake, and health. Many raised the issue of the extent of disability and premature death in their communities and are trying to feed their own young families differently: "Mum's mum, my grandmother, just died from diabetes. She lost a leg a few years back. It's the same with Mãori. They just eat themselves to death. It's a cultural crisis. I try and tell my son, 'Eat for life, don't eat yourself to death"' (Samoan female, 32 ).

Studies such as those by Jaakko Tuomilehto and others (200I) and William Knowler and others (2002) have shown that dietary modification and exercise produced good clinical results in patients with impaired glucose intolerance. However, evaluations of these programs suggest that people struggle to maintain these habits. This was also the case with the Hawaiian interventions described by Ruth Fujita and others (2004), despite encouraging early improvements in health status. Similar results emerged in the study under discussion. While approximately two-thirds of respondents acknowledged a connection between exercise and health in general discussion, less than half of interviewees (approximately thirty participants) engaged in some form of regular physical activity. The majority of those 
who exercised were young adults and teenagers; however, this activity quickly tapered off among those in their late 20 and early 30 : "We take the kids to football three times a week. I know we should be doing more ourselves [adults], but at least they are healthy" (Samoan female, 35). "I used to play a lot of netball and still try to get out and coach the younger ones. I think it's important if you want to stay healthy and look good ... but I don't know if I'll keep it up" (Cook Islander-New Zealand Māori female, 28).

At the same time, although most of the younger participants displayed knowledge of physical fitness playing a part in overall health, this was frequently offset by deep concerns regarding their own genetic profile, as summed up by the following response: "Even those who try and stay fit ... you know, they feel it's a race-but you can't beat your genes" (Māori female nurse, key respondent). This type of comment suggests that even for younger participants, internalization of the genetic message of "risk" has already taken hold.

\section{The Use of Apocalyptic Language and Its Impact on Communities}

It is evident that public health initiatives that single out certain ethnic groups, however well intentioned, may serve to increase anxiety in these communities regarding the likelihood of experiencing certain illnesses. For example, a warning given by the American Diabetes Association about the need for testing for diabetes is quite clear: "Diabetes is more common in African Americans, Latinos, Native Americans, Asian Americans and Pacific Islanders. If you are a member of one of these ethnic groups, you need to pay special attention to this test" (ADA 2005).

Scheper-Hughes argued that the pervasive idea of genetic susceptibility to obesity and type 2 diabetes means that Indigenous peoples begin to distrust their own bodies (2006). This, in turn, translates into feelings of inevitability and hopelessness at not being able to "outrun" one's genetic makeup. Australian Aboriginal star footballer Preston Campbell, for instance, reflected this concern: "The average life expectancy these days for an adult indigenous male is in the 50s [53], which is pretty scary. Even though I am a fit man, I'm likely to keel over just like that. ... That scares me" (quoted in Walter 20I0).

Aggressive and dramatic language is frequently being used to convey the urgency of medical concerns regarding Polynesian obesity, as in the title of an opening address at a WHO annual regional meeting given by New Zealand Prime Minister Helen Clark: "Obesity is a time bomb for New 
Zealand and the Pacific" (Clark 2006). Sonia Anand and Salim Yusuf used the term "tsunami of obesity" in an article in the medical journal Lancet (2OII). However, when these words and phrases appear as headlines in the public domain they potentially generate unease, distress, and even depression among those communities most affected by the range of illnesses being described. Another example is the use of apocalyptic language surrounding type 2 diabetes in the Polynesian community. One online service for medical professionals (Diabetes In Control) led with the headline "Diabetes Set to Wipe Out Whole Ethnic Populations by End of Century" and followed this with the statement "With one in two having diabetes, it could wipe out Māori and Polynesian Islanders by the end of the century, according to an international expert in the disease" (Diabetes In Control 2006). This story then became tabloid headlines such as "Maori Diabetes Fear-Threat of Extinction" (Williams 2006) and "Diabetes Could 'Wipe Out' Maori by End of Century" (New Zealand Herald 2006). These examples were taken out of context and refer to the release of conference data by Professor Paul Zimmet, whose work is cited above.

Zimmet has demonstrated an extensive personal commitment to the understanding of type 2 diabetes in disadvantaged Indigenous communities and migrant populations. Within the context of a conference of his peers, he was attempting to galvanize action on behalf of health professionals and academics in related fields. However, his comments were co-opted by tabloid newspapers and radio commentators with fatalistic claims of genetic determinism concerning Māori. This story was widely circulated in the extended Polynesian community in Australia and New Zealand, and it was still referred to five years after original publication by participants in this study. Such language and imagery without an equivalent emphasis on the preventable nature of this disease cannot be helpful, and it is patently distressing to members of a particular ethnic community to be described as being on the point of "extinction"- a term usually reserved for plants and animals.

The fear and anxiety engendered by such genetic determinism in the popular press, coupled with poor understandings of food practices that contribute to obesity-related illness, potentially add to the misinformation already circulating in the community. Many study participants, for example, reflected the perspective that type 2 diabetes was a direct genetic legacy of being Polynesian but was made worse by the consumption of sugar: "My wife has sugar diabetes. We're all trying to cut down on sugar. 
I think it's genetic-all of us Polynesians seem to get it [diabetes]. My daughters are worried about me, but I won't get tested [laughs], . . . If I get tested, then I'll know. I don't want to know" (Tongan male, mid 5os). This comment brings together several salient issues. First, many Polynesians refer to "sugar diabetes." Inherent in this term is the notion that an excess consumption of sugar causes diabetes. The naming of the condition in this way effectively precludes other influences in the acquisition of type 2 diabetes, most particularly, obesity caused by a high-fat, low-fiber diet and inadequate exercise. The second element is the reluctance to undergo testing. The inflammatory language surrounding "high risk" populations for diabetes has arguably had the effect of paralyzing rather than motivating the population to be tested. This has contributed to an idea pervasive among Polynesians that such ailments are genetically "inevitable" and that therefore testing represents an unwelcome confirmation of ill health: "Our people just do not want to be tested. They fear the worst and they just don't want to know. They don't see it as an opportunity to do something about their health status-it's the opposite. The only time they find out is when they are being tested for something else or are in prenatal care" (Māori female nurse, key respondent).

It has been argued that these "doomsday" scenarios may unintentionally lead to a certain resignation about not only contracting such illnesses but also dying as a result (Liburd 2010). As a consequence, for many Polynesians there is a growing sense of resignation about losing family members to one or another of the major obesity-related illnesses. Sensationalizing statistics on premature mortality in these ethnic groups may be intended to motivate complacent government bureaucracies and health authorities into action and to prompt these communities to adopt "healthier" lifestyles. However, instead, according to Andrew Tomlin and his colleagues (2006) as well as other researchers, this approach may be responsible for a growing fatalism in these communities, effectively becoming a disincentive to early testing and seeking treatment. As a consequence, the majority of Polynesians are left with the shadow of such irresponsible headlines.

Another critique of this position is that embedded in the legacy of genetic determinism is both the idea that "culture" and "race" are the same thing and the notion that "culture" is static. In other words, people are "culturally predisposed" to a physiological set of conditions that cannot be changed. This is both unscientific and unhelpful. It also raises the question of percentage risk. Many Polynesians-Hawaiians in particular- 
acknowledge mixed racial identities. So, within this model, where does that leave the Japanese-Hawaiian, for example, with low "genetic propensity" from the Japanese "side" and high risk from the Hawaiian "side"? What percentage of Polynesian genes would be deemed problematic?

The language of "genetic propensity" persists as an explanation for clusters of ailments when other explanations may be more useful. As pointed out by Adriana Petryna (2009), Clayton (2002), and others, the broad study of genetics continues to attract generous research funding from governments, teaching institutions, and large pharmaceutical companies despite its limited predictive capacity and its inability to address the nature and trajectory of chronic illness.

\section{Summary of Results}

- Polynesians, along with certain other marginalized non-Anglo groups, are overrepresented in statistics for obesity-related illnesses, indicating the role of socioeconomic disadvantage in relation to these rates.

- Despite this, obesity and related illnesses are progressively being described as a matter of genetic propensity among these populations.

- Poor health literacy-not understanding the multifaceted nature of these illnesses-is a significant contributor to these communities being vulnerable to genetic labeling as a "high risk" group.

- Genetic determinism based on ethnicity is having a negative impact on rates of testing for type 2 diabetes and other obesity-related diseases in Polynesian communities.

- More research is needed into ways to improve health literacy in these communities while also challenging the biomedical emphasis on genetic explanations for preventable illnesses.

- Remedial health solutions must embrace socioeconomic determinants of health as well as cultural and class resistance to the discourse about individual health.

\section{Conclusion}

At most, genetic makeup is a determinant of an individual's tendency to gain weight if consuming a high-fat diet and can be a predictor of where it is distributed on the body. In other words, even if the "obesity gene" were found, it would indicate a Polynesian predisposition for weight gain rather than constitute a sufficient cause to account for the scale of obesity- 
related illnesses in these communities. The genetic argument falls short of being able to explain the rapid rise in obesity and related illnesses globally. It fails to take into account the health implications of postcolonial marginalization, socioeconomic disadvantage, or the impact of globalization on food intake and lifestyle habits. As Polynesians are affected by each of these phenomena, it is necessary to undertake more research concerning the incidence and interaction of these factors.

Polynesians, like many other colonized people, appear trapped in a food cycle that is demonstrably bad for their health and bears little or no resemblance to their precontact diet and lifestyle. People do not eat what is recommended but rather what is available to them depending on household economics and what they consider desirable in terms of both "traditional" and commercially produced food. The patterns around food and dietary behaviors are deeply embedded in the cultural practices of social exchange, obligation, and interdependence that inform household, family, and community life. It is clearly not these cultural practices that are causing obesity, as these patterns were well established prior to the upsurge in obesity and accompanying illness. Rather, a myriad of issues related to colonial dispossession and contemporary marginalization converge around food and health. Therefore, capacity building to improve health literacy in the extended Polynesian community is essential to promote understandings of the correlation between excessive food consumption, a sedentary lifestyle, and the likelihood of acquiring an illness that may otherwise be preventable.

OUR HEARTFELT THANKS to three anonymous reviewers for their detailed, thoughtful comments on earlier versions of this article.

\section{Notes}

I In the context of this paper, "Polynesian" refers to Hawaiians, New Zealand Māori, Independent Samoans, Tongans, Niueans, and Cook Islanders.

2 There is substantial New Zealand government data regarding the health of Māori and Polynesian Pacific Islanders in the country. For links to numerous sources, see NZMH 20I3a, 20I3b.

3 For more detailed information on why this should be considered an underestimate, see Hamer 2007 and 2008. 
4 "Snowballing" is a term that describes the recruitment process whereby one respondent suggests others who may be interested in participating. There is then an ethical requirement by the researcher to ensure the suggested participant is apprised of what is entailed and meets other criteria established for recruitment.

\section{References}

ADA, American Diabetes Association

2005 Diabetes Risk Test. Available from ADA website: http://www.diabetes .org/risk-test.jsp [accessed I 2 Oct 2009]

Anand, Sonia, and Salim Yusuf

20I I Stemming the Global Tsunami of Cardiovascular Disease. Lancet 377 (9765): 529-532.

ABs, Australian Bureau of Statistics

2006 Census of Population and Housing. Available from ABS website: http://www.abs.gov.au/websitedbs/censushome.nsf/home/Census [accessed 30 March 2009]

Bedford, Suzanne, Mieke van Driel, Neil Smart, and Nera Komaric

2009 Care of Chronic Diseases in Queensland's Culturally and Linguistically Diverse (CALD) Communities: A Qualitative Study in Primary Care. West End, QLD: Ethnic Communities Council of Queensland; Robina, QLD: Primary Health Care Research Evaluation and Development Program of Bond University, Queensland. Online at http:// www.eccq.com.au/wp-content/uploads/20I2/o2/CALD_qualitative

Bradby, Hannah _MVD_I20909_W2003.pdf [accessed 5 Sept 2013]

2000 Genetics and Racism. In The Troubled Helix: Social Psychological Implications of the New Human Genetics, edited by Theresa Marteau and Martin Richards, 295-3I6. Cambridge, uk: Cambridge University Press.

Brewis, Alexandra, Stephen McGarvey, J Jones, and Boyd Swinburn I998 Perceptions of Body Size in Pacific Islanders. International Journal of Obesity and Related Metabolic Disorders 22 (2): I 85-I 89.

Chang, Virginia, and Nicholas A Christakis

2000 Medical Modelling of Obesity: A Transition from Action to Experience in a 2oth Century American Medical Textbook. Sociology of Health and Illness 24 (2): I 5 I-I77.

Clark, Helen

2006 Obesity Is a Time Bomb for New Zealand and the Pacific. Opening address, World Health Organization annual regional meeting, Auckland, September. 
Clayton, Barbara

2002 Rethinking Postmodern Maladies. Current Sociology 50 (6): 839$85 \mathrm{I}$.

Consillio, Kristen

20I3 Life Spans, Diseases Still Worse than Other Residents'. Honolulu Star-Advertiser, 25 September.

Craig, P, K Samaras, J Freund, N Culton, V Halavatau, and L Campbell

2003 BмI Inaccurately Reflects Total Body and Abdominal Fat in Tongans. Acta Diabetologica 40 (I): s282-s285.

Cram, Fiona

200I Rangahau Māori: Tona Tika, Tona Pono: The Validity and Integrity of Māori Research. In Research Ethics in Aotearoa New Zealand, edited by Martin Tolich, 35-52. Auckland: Longman.

Davis, Tom

I992 Island Boy: An Autobiography. Suva: Institute of Pacific Studies, University of the South Pacific; Christchurch: MacMillan Brown Centre for Pacific Studies, University of Canterbury.

Denzin, Norman K, Yvonna S Lincoln, and Linda Tuhiwai Smith 2008 Handbook of Critical and Indigenous Methodologies. Thousand Oaks, CA: Sage.

Diabetes in Control

2006 Diabetes Set to Wipe Out Whole Ethnic Populations by End of Century. Diabetes in Control website: http://www.diabetesincontrol .com/index.php? option=com_content $\&$ view-article $\&$ id $=4322$ [accessed ro Oct 2009]

Duckett, Stephen

2008 The Australian Health Care System. Third edition. New York: Oxford University Press.

Durie, Mason

2003 Ngā Kāhui Pou: Launching Māori Futures. Wellington: Huia Press.

Ferreira, Mariana L, and Gretchen C Lang

2006 Deconstructing Diabetes. In Indigenous Peoples and Diabetes: Community Empowerment and Wellness, edited by Mariana Ferreira and Gretchen Lang, 3-27. Durham, NC: Carolina Academic Press.

Foliaki, Sunia, and Neil Pearce

2003 Prevention and Control of Diabetes in Pacific People. British Medical Journal 327 (74I2): 437-439.

Fujita, Ruth, Kathryn L Braun, and Claire K Hughes

2004 The Traditional Hawaiian Diet: A Review of the Literature. Pacific Health Dialog I I (2): 250-259. 
Furubayashi, Jill K, and Mele A Look

2005 Type 2 Diabetes in Native Hawaiians and Pacific Islanders in Hawaii. Pacific Health Surveillance and Response I 2 (2): I03-I Io.

Gonda, E, and K Katayama

2006 Big Feet in Polynesia: A Somatometric Study of the Tongans. Anthropological Science I I4 (2): I27-I3 I.

Hamer, Paul

2007 Māori in Australia: Ngā Māori Te Ao Moemoeā. Wellington: Ministry for Māori Development, Te Puni Kokiri.

2008 One in Six? The Rapid Growth of the Maori Population in Australia. New Zealand Population Review 33/34:I 53-I76.

Harry, Debra

200I Biopiracy and Globalization: Indigenous Peoples Face a New Wave of Colonialism. Talk given for the International Forum on Globalization Teach-in, New York, February. Available from the Indigenous Peoples Council on Biocolonialism website: http://www.ipcb.org/ publications/other_art/globalization.html [accessed 5 Sept 20I3]

Heil, Daniela

2009 Embodied Selves and Social Selves: Aboriginal Well-Being in Rural New South Wales, Australia. In Pursuits of Happiness: Well-Being in Anthropological Perspective, edited by Gordon Matthews and Caroline Izquierdo, 88-ro8. Oxford: Berghahn Books.

King, Hilary, Ronald E Aubert, and William H Herman

I998 Global Burden of Diabetes I995-2025: Prevalence, Numerical Estimates, and Projections. Diabetes Care 2 I (9): I4 I4-I43 I.

Knowler, William, E Barrett-Connor, S E Fowler, and others

2002 Reduction in the Incidence of Type 2 Diabetes with Lifestyle Intervention or Metformin. New England Journal of Medicine 346:393403.

Lassetter, Jane

2010 The Integral Role of Food in Native Hawaiian Migrants' Perceptions of Health and Well-Being. Journal of Transcultural Nursing 22 (I): $63-70$.

Liburd, Leandris C

2010 Diabetes and Health Disparities: Community-Based Approaches for Racial and Ethnic Populations. New York: Springer Publishing.

Lupton, Deborah

I996 Food, The Body and the Self. London: Sage.

2003 Medicine as Culture. Second edition. London: Sage.

McCarty, Daniel J, and Paul Zimmet

200I Pacific Island Populations. In The Epidemiology of Diabetes Mel- 
litus: An International Perspective, edited by Jean-Marie Ekoé, Paul Zimmet, and Rhys Williams, 239-245. Chichester, uk: Wiley.

Montoya, Michael

2007 Do Genes Explain Diabetes Health Disparities between Ethnic Groups? Available from Endocrine Today website: http://www .endocrinetoday.com/view.aspx? rid=24056 [accessed 6 May 2009]

Neel, James V

I962 Diabetes Mellitus: A “Thrifty” Genotype Rendered Detrimental by "Progress"? American Journal of Human Genetics I4 (4): 353-362. I982 The Thrifty Genotype Revisited. In The Genetics of Diabetes Mellitus, edited by Johannes Köbberling and Robert Tattersall, 283-293. London: Academic Press.

New Zealand Herald

2006 Diabetes Could "Wipe Out" Maori by End of Century. I4 November. http://www.nzherald.co.nz/nz/news/article.cfm?c_id=I \&objectid =I04 I0625\&pnum=I [accessed 5 Sept 20I3]

NZMH, New Zealand Ministry of Health

20I3a Māori Health Data and Stats. Available from NZMH website: http://www.maorihealth.govt.nz/moh.nsf/indexma/diabetes [accessed 27 Sept 2013]

20I3b Pacific Health Data and Stats. Available from NZMH website: http://www.health.govt.nz/nz-health-statistics/health-statistics-and -data-sets/pacific-health-data-and-stats [accessed 27 Sept 20I3]

Obesity Task Force

2008 Obesity Key Facts and Statistics. New Zealand Ministry of Health. Available from: http://www.moh.govt.nz/moh.nsf/indexmh/obesity -key-facts [accessed I 2 June 2009]

омн, Office of Minority Health, US Department of Health and Human Services 2009 Obesity and Native Hawaiians/Pacific Islanders. Available on the омн website: http://minorityhealth.hhs.gov/templates/content.aspx ?lvl=3\&lvlID=537\&ID=8736 [accessed 2 I May 20 I0]

Page, Anthea, Sarah Ambrose, John Glover, and Diana Hetzel

2007 Atlas of Avoidable Hospitalisations in Australia: Ambulatory CareSensitive Conditions. Adelaide: Public Health Information Development Unit, The University of Adelaide.

Pearce, Neil, Sunia Foliaki, Andrew Sporle, and Chris Cunningham

2004 Genetics, Race, Ethnicity and Health. British Medical Journal 328 (7447): I070-I072. http://www.ncbi.nlm.nih.gov/pmc/articles/PMC 4038561

Petryna, Adriana

2009 When Experiments Travel: Clinical Trials and the Global Search for Human Subjects. Princeton, NJ: Princeton University Press. 
Rodriguez, Lena

2009 Science or Bio-piracy? A Sociological Examination of Genetic Research into the "Warrior Gene" in Modern Polynesians. Paper presented at "The Future of Sociology," the annual conference of the Australian Sociological Association (TASA), Canberra, I-4 December.

2012 "Obesity Is Killing Our People": The Social Constructions of Obesity and Implications for Health and Well-Being in the Maori and Pacific Island Community in Australia. PhD thesis, University of Newcastle, Australia.

Sanga, Kabini

2004 Making Philosophical Sense of Indigenous Pacific Research. In Researching the Pacific and Indigenous Peoples: Issues and Perspectives, edited by Tupeni Baba, 'Okusitino Māhina, Nuhisifa Williams, and Unaisi Nabobo-Baba, 4I-52. Auckland: Centre for Pacific Studies, University of Auckland.

Scheper-Hughes, Nancy

2006 Diabetes and Genocide: Beyond the Thrifty Gene. In Indigenous Peoples and Diabetes: Community Empowerment and Wellness, edited by Mariana Ferreira and Gretchen Lang, xvii-xxiii. Durham, NC: Carolina Academic Press.

Shilling, Chris

2003 The Body and Social Theory. Second edition. Thousand Oaks, CA: Sage.

Simmons, David, Tim Kenealy, and D J Scott

2000 Implementing the South Auckland Diabetes Plan: Barriers and Lessons. New Zealand Medical Journal I I 3 (I I I 6): 364-366.

Stauffer, Brian, and Christopher DeSouza

2010 Epigenetics: An Emerging Player in Health and Disease. Journal of Applied Physiology ro9 (I): 230-23I.

Sundborn, Gerhard, Patricia Metcalf, D Gentles, and others

2008 Ethnic Differences in Cardiovascular Disease Risk Factors and Diabetes Status for Pacific Ethnic Groups and Europeans in the Diabetes Heart and Health Survey (DHAH) 2002-2003, Auckland New Zealand. New Zealand Medical Journal I 2I (I 28I): 28-39.

Sundborn, Gerhard, Patricia Metcalf, Robert Scragg, and others

2007 Ethnic Differences in the Prevalence of New and Known Diabetes Mellitus, Impaired Glucose Tolerance, and Impaired Fasting Glucose. Diabetes Heart and Health Survey (DHAH) 2002-2003, Auckland New Zealand. New Zealand Medical Journal I 20 (I 257): 52 I-524.

Tomlin, Andrew, Murray Tilyard, Andrew Dawson, and Susan Dovey 2006 Health Status of New Zealand European, Māori, and Pacific Patients 
with Diabetes in 242 New Zealand General Practices. New Zealand Medical Journal II9 (I235) [online]. Available from http://www .nzma.org.nz/journal/I I 9-I 235/2004/ [accessed 4 June 2008]

Tuomilehto, Jaakko, Jaana Lindström, Johan G Eriksson, and others 200 I Prevention of Type 2 Diabetes Mellitus by Changes in Lifestyle among Subjects with Impaired Glucose Tolerance. New England

Walter, Brad Journal of Medicine 344:I343-I350.

2010 We Can't Forget But We Can Forgive: Campbell. Sydney Morning Herald, weekend edition Sportsday, I3-I4 February.

Williams, Paora N, Marion A Gray, Tania M Ka'ai, and others

2003 Maori Men's Perceptions and Experiences of Health Seeking for Prostate Health Problems in New Zealand. Pacific Health Dialog Io (2): $7 \mathrm{I}-78$.

Williams, Peter

2006 Maori Diabetes Fear-Threat of Extinction. Sydney Daily Telegraph, I 5 November.

Zhang, Qi and Youfa Wang

2004 Socioeconomic Inequality of Obesity in the United States: Do Gender, Age, and Ethnicity Matter? Social Science and Medicine 58 (6): I I 7 I-I I 80.

Zimmet, Paul

2005 Coca-Colonisation and the Diabesity Epidemic. Around the Globe 2 (3): 4-9.

Zimmet, Paul, and Charles R Thomas

2003 Genotype, Obesity and Cardiovascular Disease-Has Technical and Social Advancement Outstripped Evolution? Journal of Internal Medicine 254 (2): I I4-I25. http://onlinelibrary.wiley.com/doi/IO .I046/j.I365-2796.2003.0II70.x/full

Zimmet Paul, Max de Courten, Allison M Hodge, and Jaakko Tuomilehto $200 \mathrm{I}$ Epidemiology, Evidence for Prevention: Type 2 Diabetes. In The Epidemiology of Diabetes Mellitus: An International Perspective, edited by Jean-Marie Ekoé, Paul Zimmet, and Rhys Williams, 4I-50. Chichester, uk: Wiley.

\section{Abstract}

For Western health professionals, obesity and related illnesses are viewed as preventable and arising from lifestyle choices; however, for Polynesians and many other Indigenous peoples, these same diseases are regarded as genetically deter- 
mined. This article examines this contradiction and questions whether high clusters of these illnesses are evidence of "faulty genes" or are a product of other socioeconomic and cultural influences related to postcolonial marginalization. We suggest that both the ways genetic findings are disseminated and a limited understanding of their predictive capacity may in fact contribute to certain fatalistic attitudes within these populations. Labeling Polynesians "at risk" can engender fear in the community, arguably leading to a greater reluctance of people to be tested. In turn, this leads to more Polynesians presenting late for treatment as well as to poorer outcomes. Our article focuses on the results of qualitative interviews with sixty-seven Polynesian migrants to Australia.

KEYWORDs: Polynesian, Indigenous health, obesity, genetics, risk, migration

\section{Appendix A. Summary of Family Participants' Household Densities and Migration Histories}

\section{Māori Families}

Eastern Sydney I: 2 adults with 2 dependent children $^{\mathrm{I}}$

Two adults born in New Zealand, two children born in Australia. Migrated to Australia twenty-five years ago.

Eastern Sydney 2: 3 adults with 5 dependent children

Mother, father, their own three children, mother's sister, and her two children. All adults born in New Zealand, all five children born in Australia. Migrated twelve years ago.

Eastern Sydney 3: 4 adults

Disabled mother, her three sons, one of whom is her primary caregiver. Three adults born in New Zealand, one in Australia. Migrated to Australia twenty-five years ago.

Southern Sydney I: 7 adults, 5 dependent children

Mother, father, their two adult children (one with partner and child), three teenage nieces, mother's sister, her husband, and their dependent child. All adults born in New Zealand, all children born in Australia. Migrated to Australia twenty years ago.

Southern Sydney 2: I adult (single mother), ${ }^{\mathrm{I}}$ I dependent child

Single mother born in New Zealand, child born in Australia. Migrated five years ago. 


\section{Tongan Families}

Newcastle I: 8 adults and I dependent child

All adults born in Tonga, with exception of sister and partner born in

New Zealand. Main family migration around twenty-two years ago to New Zealand. Migrated to Australia seventeen years ago. Child born in Australia.

Newcastle 2: 7 adults and 3 dependent children

Mother, father, their three dependent children, two grandparents, father's two sisters, mother's niece. Two oldest participants born in Tonga, remaining family members born in New Zealand. Migrated to Australia five years ago.

\section{Samoan Families and Samoan-Māori Family}

Lake Macquarie: 6 adults, $8+$ dependent children

Mother, father, three sons, four daughters, father's sister, two nieces, one nephew, one grandmother, and assorted grandchildren (infant to ro years old) also live with them.

Parents born in Sāmoa and moved to New Zealand as newlyweds (1979). Their six children were born in New Zealand. Migrated to Australia ten years ago. Grandchildren born in Australia.

Sydney: 8 adults, 2 dependent children

Mother, father, their own four children, mother's brother, mother's niece, father's sister, and her child. Five related adults born in New Zealand, two eldest teenage children born in New Zealand, youngest teenage child and two dependents born in Australia. Migrated to Australia eight years ago.

Sydney Samoan-Māori: 5 adults, 2 dependent children

Mother, father, their two children, father's sister and her husband, mother's adult niece.

Māori husband and Samoan wife both born in New Zealand. Eldest child born in New Zealand and youngest in Australia. Migrated to Australia six years ago.

\section{Cook Islands Family}

Sydney: 9 adults, 3 dependent children

Mother, father, their three teenage children, their adult son, his partner, and their three children, mother's aunt, grandmother. Two primary adults born in the Cook Islands, eldest children born in New 
Zealand, grandchildren born in Australia. Migrated to Australia ten years ago.

\section{Country of Birth}

The majority of respondents were born in New Zealand, including Islanders. Age of migration was typically mid to late $20 s$. Most children in the household studies were born in Australia. Average length of time since migration was $\mathrm{I} 3.5$ years.

\section{Notes}

I Those over age 18 are defined as adults; those under 18 are defined as dependent children.

2 There were other unpartnered women with children in this cohort, but they had chosen to live with their extended families and were therefore interviewed as part of the broader household context.

Appendix B. Summary of Individual

and Focus-Group Participants

Individual Participants

$\begin{array}{llll}\text { Ethnicity } & \text { Age } & \text { Gender } & \text { Country of Birth } \\ \text { Māori } & \text { mid 30s } & \text { Male } & \text { New Zealand } \\ \text { Māori } & 22 & \text { Male } & \text { Australia } \\ \text { Māori } & 35 & \text { Female } & \text { New Zealand } \\ \text { Māori } & \text { early 50s } & \text { Female } & \text { New Zealand } \\ \text { Cook Islander-Māori } & \text { mid 30s } & \text { Male } & \text { New Zealand } \\ \text { Cook Islander } & 60 & \text { Male } & \text { New Zealand } \\ \text { Samoan-Māori } & 18 & \text { Male } & \text { New Zealand } \\ \text { Tongan } & 22 & \text { Female } & \text { Australia } \\ \text { Tongan } & \text { mid 40s } & \text { Female } & \text { Tonga }\end{array}$


Focus Group A (Newcastle)

$\begin{array}{llll}\text { Ethnicity } & \text { Age } & \text { Gender } & \text { Country of Birth } \\ \text { Māori } & 22 & \text { Male } & \text { New Zealand } \\ \text { Samoan } & 22 & \text { Male } & \text { New Zealand } \\ \text { Samoan } & 22 & \text { Female } & \text { New Zealand } \\ \text { Tongan } & 18 & \text { Female } & \text { Australia } \\ \text { Tongan } & 24 & \text { Female } & \text { Australia } \\ \text { Tongan } & 25 & \text { Female } & \text { Australia } \\ \text { Tongan } & 20 & \text { Female } & \text { New Zealand }\end{array}$

Focus Group B (Sydney)

$\begin{array}{llll}\text { Ethnicity } & \text { Age } & \text { Gender } & \text { Country of Birth } \\ \text { Māori } & 22 & \text { Female } & \text { New Zealand } \\ \text { Māori } & 20 & \text { Female } & \text { Australia } \\ \text { Māori } & 19 & \text { Female } & \text { New Zealand } \\ \text { Māori } & 24 & \text { Male } & \text { New Zealand } \\ \text { Māori } & 18 & \text { Male } & \text { Australia } \\ \text { Samoan } & 22 & \text { Female } & \text { New Zealand } \\ \text { Samoan } & 22 & \text { Male } & \text { New Zealand } \\ \text { Tongan } & 23 & \text { Male } & \text { Tonga }\end{array}$

Of these 24 participants, 5 were engaged in full-time study, 3 in part-time study while working, 4 were unemployed, 10 were employed in unskilled labor), 1 was a benefits recipient, and 1 was employed as a professional musician. 